\title{
A RECONSTRUCTION OF THE THINKING OF PRIMARY SCHOOL CIVICS EDUCATION TEACHING AS YADNYA IN THE REALIZATION OF DHARMA AGAMA AND DHARMA NEGARA
}

\author{
I Wayan Kertih \\ Fakultas Ilmu Sosial Universitas Pendidikan Ganesha \\ email: iwayankertih@gmail.com
}

\begin{abstract}
This research was aimed at testing the effectiveness of primary school Civics Education teaching when it was taken as a yadnya in affecting learning achievement in the aspects of civic knowledge, value orientation, and behavior both simultaneously and partially. The study was done as classroom action research and quasi-experimental study using the post test only control group design. The data were obtained from teachers selected purposively and from students selected using the multistage random sampling. The data were collected using the Civics knowledge test, value inventory, and the self evaluation format. The data were analyzed using descriptive statistics and multivariate variance analysis (MANOVA). The results showed: (1) descriptively, Civics Education as yadnya Teaching Model caused the students to obtain learning achievement falling into the medium category in civic knowledge, the high category in civic value orientation, and the medium category in civic behavior; (2) the implementation of Civics Education teaching as yadnya had a significant effect on Civics Education learning achievement in the aspects of civic knowledge, value orientation, and behavior both simultaneously and partially.
\end{abstract}

Keywords: civics education teaching as yadnya,civics education learning achievement

\section{REKONSTRUKSI PEMIKIRAN PEMBELAJARAN PKN SD SEBAGAI YADNYA DALAM PERWUJUDAN DHARMA AGAMA DAN DHARMA NEGARA BERBASIS KONSTRUKTIVISME}

\begin{abstract}
Abstrak: Penelitian ini bertujuan menguji efektivitas model pembelajaran PKn SD sebagai yadnya dalam memengaruhi hasil belajar pada aspek pengetahuan, orientasi nilai, dan tingkah laku kewarganegaraan baik secara bersama-sama dan parsial. Penelitian dilakukan dengan penelitian kelas dan penelitian eksperimen semu menggunakan desain postes saja dengan kelompok kontrol. Data diperoleh dari guru dan siswa yang dipilih secara purposif untuk guru dan multistage random sampling untuk siswa. Data dikumpulkan dengan metode pemberian tes pengetahuan kewarganegaraan, inventori nilai, dan format penilaian diri. Data dianalisis dengan teknik statistik deskriptif dan analisis varian multivariat (manova). Hasil penelitian ini menunjukkan: (1) secara deskriptif model pembelajaran PKn sebagai yadnya memberikan kategori hasil belajar PKn siswa yang cukup pada aspek pengetahuan kewarganegaraan, kategori tinggi pada aspek orientasi nilai kewarganegaraan, dan kategori cukup pada aspek tingkat laku kewarganegaraan; (2) penerapan model pembelajaran berpengaruh secara signifikan terhadap hasil belajar PKn siswa pada aspek pengetahuan, orientasi nilai, dan tingkah laku kewarganegaraan baik secara bersama-sama maupun secara parsial.
\end{abstract}

Kata kunci: pembelajaran PKn sebagai yadnya, hasil belajar PKn

\section{INTRODUCTION}

Education cannot be separated from the sociocultural community context and process. It means that education asan effort to shape behavior, to transfer knowledge, to develop the cognitive process and values, to teach the way how to learn and to teach essential cognitive and so- cial skills as well as truth will also be determined by society's prevailing world view and values (Pai, 1990:1). The development of educational program and process in Bali, parallel to the above framework of thinking is assumed not to be separable from Balinese context and the sociocultural process. Empirically, some studies 
have indicated the phenomenon (Subagia, 2000: 79; Sukadi, 2006:406).

In today's Balinese life, spiritual-cultural approach is still held firmly and is implemented adaptively and flexibly in developing the paradigm and operationalization of life practices. Parallel to this, the development of educational programs can also be implemented based on the spiritual cultural development (Sukadi, 2006: 3). Unfortunately, since the domination and hegemony of the national educational practice that tends to neglect humanistic-religious values, the spirit of education that is based on sacred moral values have tended from time to time to change and has consequently shown a phenomenon of secularization (Widja, 2007:7487). Inthe educational world, like in secular countries, there is a tendency to separate religious ideology and science ideology. Such practice of education is found in the teaching and learning activities at schools that are not touched by spiritual values but are stressing the attainment of improvement in the intellectual skill that tends to be rationalistic-materialistic (Somantri, 2001:76).

The Civics Education teaching and learning practice at schools is also not separable from the effect of the market ideology of capitalism. There is a very little contact with local spiritual values that are developed and integrated in Civics Education teaching that studies the relationship between the nation and its citizens. This condition of much concern correlates with the phenomenon of the social and national life that shows relationships between the citizen and the nation in which corruption, collusion, and nepotism and other social diseases become the dominant characteristics (Djahiri, 2006:2630).

If education does not want to uproot young generation from their cultural root that tends to be religious, the materialistic educational practice needs to be transformed into and is oriented toward humanistic-religious practice without neglecting the rationalistic-empirical values. Is not it like what was stated by Einstein (Somantri, 2001:55) "Religion without science is lame, but science without religion is blind."
It is in this connection that the point of view, belief, values, and the teaching and learning practice that make teaching as a form of worship or holy sacrifice or yadnya, i.e., a holy and earnest offering toIda Sang Hyang Widhi Wasa (God the Almighty) find a fertile land (Subagia, 2000: 25; Sukadi, 2009:150).

In this context, the teaching and learning process needs to integrate physical, intellectual, academic, social, moral and spiritual activities. For the community, Civics Education teaching at schools needs to be taken as and developed in the perspective of spiritual and cultural perspective without neglecting the ideals of the commitment of the life of the nation, and the development of the ability to think globally. In the language of the vision of education it can be formulated as to educate people that have the ability to think globally, act locally, and commit nationally (Winataputra, 2001:28-30). In relation to this, Civics Education at schools needs to be developed from various perspectives, as follows.

First, in the ideological perspective, Civics Education teaching practice needs to be developed based on Pancasila ideology that has an open character so that it can still accept ideological elements of the society that are still relevant such as religious ideologies (one of which is that of Hinduism), knowledge ideology, and local community ideology (Fukuyama, 1985; Giroux and Pennao, 1979; Soeprapto, 2013: 266; Merdhana, 2000:20).

Second, ontologically and epistemologically, the studies of Civics Education that make the relationship of the nation and the citizens (in the ideological, political, legal, values and moral perspectives) as the object of study do not need only to be reviewed through the Western scientific perspective that is value free. The object of Civics Education can also be seen from the scientific perspective that can still keep the balance for the subjects of the nation in realizing their dharma agama and dharma negara. In this way the relationship between the citizens and the nation is not only developed based on the rationalistic-empiric morality, but it also 
needs to be based on social, cultural, and spiritual values (Subiyantoro, 2013:339).

Third, pedagogically (psychologically) and methodologically, the Civics Education teaching practice in the classroom has to involve not only low level cognitive activities but Civics Education teaching also needs to integrate environmental, physical, mental, social, moral, and spiritual activities at the same time. In this way, Civics Education as education in knowledge, education in values, and education in personality, as well as the development of skill of citizenship can be fully realized comprehensively, powerfully and meaningfully based on the principles of constructivism, contextual teaching and learning, joyful learning, and a life-skill-based teaching (Depdiknas, 2004; NCSS, 2000; Sukadi, 2006:400).

It is a kind of Civics Education that is expected to develop and integrate the students' competences in realizing dharma agama and dharma negara at the same time based on Pancasila values and the 1945 Constitution. Here it is also believed that the development of social political and national life is not a political life that is value free or even a dirty political life; but it must be the development of a political life that applies political ethics principles based on religious values and Pancasila as well as the 1945 Constitutional values (Maliki, 2004:xiiixxix).

Since the development of such an idea is still limited, research that develops spiritual culture in the social and civics studies in particular needs needs to be conducted. With this research it is expected that the substances of Civics Education studies that integrate Balinese local spiritual cultural concepts can be reconstructed. In addition, there needs also to be developed the nature of Civics Education teaching and learning as an ideological, political, legal, social, moral and character education based on Bali Hindu community political moral values

\section{METHODS}

This study was conducted using multiyear research and development (R\&D) design (Borg and Gall, 1989). This study was a second year study. Its aimwas to test the effectiveness of the implementation of Civics Education teaching as yadnya in improving Civics Education learning achievement in the aspects of civic knowledge, value orientation, and behavior. For this second year study, the approaches used were classroom action research and quasiexperimental study using the posttest only control group design. To reach the objective, the data that were needed to be analyzed in this study were about the students' Civics Education learning achievement in the aspects of civic knowledge, value orientation, and behavior. The subjects were teachers who were selected purposively and students who were selected by multistage random sampling. The number of the teachers involved was 8 and that of the students was 271.

The data collection was done by administering a Civics Education knowledge test, value inventory and self evaluation format. All the main data have been tested in terms of validity and reliability. The data obtained were then analyzed statistically using descriptive statistics and multivariate variance analysis (Manacova) (Norusis, 1986:103-152).

\section{RESULT AND DISCUSSION}

The following are the results of the study that was carried out in the second year which convers: (1) the result of the classroom action research; and (2) the result of the experimental study.

\section{Result of Classroom Action Research}

The phase of the study of the teaching in the classroom in this study was conducted in three cycles of teaching. The aim was to find out the syntax of an effective primary school Civics Education as yadnya teaching that produces learning achievement in the aspects of civic knowledge, civic value orientation, and civic behavior. The first cycle was done to attain the students' basic competence of ability to understand dedicational values or dedication to the nation and the state of Indonesia. The teaching was done in two meetings which were added by a co-curricular task. An instrument for 
evaluating learning achievement was prepared for civic knowledge, Civics Education teaching was done using a syntax consisting of 10 phases of teaching. The ten phases were: (1) praying together; (2) doing dharma gita as apperception; (3) informing the objective and use of teaching as yadnya; (4) the brahmacari phase of learning. Brahmacari means self learning or individual learning; (5) the grehasta phase of learning. That is group learning or cooperative learning; (6) the wanaprasta phase of learning, that is a reflection over the learning experience; (7) the biksukha phase of learning, that is experiencing/doing ayadnya; (8) drawing a conclusion of the learning outcome; (9) closing prayer; and (10) a follow-up.

Civics Education teaching as yadnyathat was applied in 10 phases above was satisfactorily done by the teachers. The characteristics of teaching which were productive, active, effective and joyful have also been realized by them. Although there were some difficulties that the teachers and the students experienced in implementing Civics Education teaching as yadnya model which was supplemented by the material of Dharma Agama and Dharma Nega$r a$. First, the teachers and the students thought that the supplementary material was too much and complex. Second, the implementation of the Civics Education model based on yadnya needed much equipment and many teaching media. Third, although the concepts used in developing the model were contextual, the teachers who did not know the Balinese local concepts well and the Hinduism concepts felt it rather difficult to understand and implement the rather complex model of teaching. The students also found it difficult to understand the Dharma and Dharma Negara learning material since many Balinese local concepts and Hinduism concepts that needed to be learned. This was caused by the fact that the teachers and the students thought that all of the concepts used had to be learned. Fourth, implementing this kind of teaching model was not easy for the teachers who were not in the habit of implementing the contextual teaching model using constructivist approach.
The learning achievements reached by the students in the first cycle of teaching is shown in Table 1.

Table 1. Students' Learning Achievement in the Aspect of Civic Knowledge in the First Cycle

\begin{tabular}{cccccc}
\hline No & $\begin{array}{c}\text { Interval } \\
\text { Category }\end{array}$ & $\begin{array}{c}\text { Multiple } \\
\text { Choice }\end{array}$ & $\begin{array}{c}\text { Short } \\
\text { Completion }\end{array}$ & $\begin{array}{c}\text { Essay } \\
\text { All } \\
\text { toget } \\
\text { her }\end{array}$ \\
\hline 1. & $<4.00$ & 2 & 3 & 4 & 4 \\
2. & $4.00-5.4$ & 5 & 4 & 6 & 3 \\
3. & $5.5-6.9$ & 12 & 10 & 15 & 17 \\
4. & $7.0-8.4$ & 16 & 15 & 10 & 11 \\
5. & $8.5-10.00$ & 5 & 8 & 5 & 5 \\
& & 40 & 40 & 40 & 40 \\
\hline
\end{tabular}

Data show that the students' absorptive capacity in Civics Education was 65.6. By using the criterion of minimal mastery of 6.00 for Civics Education, the level of mastery in Civics Education reached in Cycle 1 was $75 \%$.

On the basis of the data it can be interpreted that the absorptive capacity of the students was still in the fair category and there was $34.4 \%$ of the material that was not mastered by the students. In terms of the level of mastery for the class, there was still around $25 \%$ of the students who did not reach the minimal level of mastery. The non optimum level of mastery learning was probably caused by the difficulty level that was high enough. This high enough level of difficulty, according to the teachers, was probably related to the habit in evaluating $\mathrm{Ci}$ vics Education so far. The subject so far tended to be characterized as something that had to be memorized, while in this teaching the evaluation instrument was developed through more orientation toward the use of high level thinking.

Civics Education teaching as yadnya in the second cycle was done to reach the basic competence of internalizing dedication value or dharma for the state and the nation of Indonesia. The teaching was done in three meetings which were added with a co-curricular task. The evaluation instrument was prepared for the aspect of civic value orientation and the sugges- 
tions for correction given by the team of researchers, the teaching was done by using the same syntax of teaching having ten phases. The correction was only stressed on the effectiveness of the implementation of each phase of learning.

Civics Education teaching as yadnya that was implemented in ten phases of teaching by the teachers was getting better. The characteristics of teaching that are productive, active, creative, and joyful could be maintained by the teachers even it had been realized better. The difficulties in implementing the teaching could also be overcome by the teachers well except for the aspect of provision of facilities and teaching media.

The learning achievement of the students in the second cycle is shown in Table 2.

Table 2. Students' Learning Achievement for the Aspects of Thinking and Value Orientation

\begin{tabular}{cccc}
\hline No. & Category & Thinking & Value Orientation \\
\hline 1. & $<4.00$ & - & - \\
2. & $4.00-5.49$ & 5 & - \\
3. & $5.50-6.99$ & 10 & 12 \\
4. & $7.00-8.49$ & 18 & 18 \\
5. & $8.50-10.00$ & 7 & 10 \\
\hline
\end{tabular}

Based on the data above it can be interpreted that the absorptive capacity of the students in thinking and value orientation fell into the high category. However, this had not been optimum yet. There were still $28.75 \%$ of absorptive capacity in thinking and $22.5 \%$ in value orientation that were not reached by the students in learning. In terms of the classroom level of mastery, there were still $17.5 \%$ students who did not reach the minimum level of mastery in thinking, while in value orientation, there were still $30 \%$ of the students who did not reach it.

The non optimal attainment of the absorptive capacity and the mastery level of the students in these values, according to the teachers was partly caused by the students' inability to learn about values in the previous lessons. Civics Education teaching had so far stressed the aspect of cognition in remembering facts, concepts, and events. Mean while, in the teaching there occurred a process that stressed more on knowledge and less activities that enable the internalization process of values (Budimansyah dan Sapriya, 2012).

Civics Education teaching as yadnya in the third cycle was done to reach the basic competence of ability to apply the values of dedication or dharma for the nation and the state of Indonesia in daily life. The teaching was done in two meetings, which was added with a cocurricular task as homework. The evaluation instrument of Civics Education that had been prepared for civic value orientation based on suggestions by the team of researchers and $\mathrm{Ci}$ vics Education teaching kept on being done in the same syntax using ten phases of teaching. The correction was only stressed on the effectiveness of the implementation of each phase. Civics Education teaching as yadnya that was implemented in the ten phases had become more satisfactorily done by the teachers. The characteristics of teaching which are productive, active, creative, effective, and joyful could also been realized well.

The evaluation of learning achievement of the students in the third cycle could not be done by the teachers due to time limitation. Actually, the teaching needed three meetings, but because of the time limitation it was only done in two meetings.

\section{Results of the Experimental Study}

The experimental study that was conducted was aimed at comparing descriptively the results of primary school Civics Education teachings at grade 6 in Bali in the aspects of civics knowledge, civic value orientation and civic behavior between the uses of Civics Education as yadnya model and the conventional Civics Education model. In addition, it tested the four statistical hypotheses of the study through an experiment as follows.

First, simultaneously there is no significant difference in the students' Civic Education learning achievement in civic knowledge, value orientation, and behavior between the results of 
the implementation of teaching as yadnya model and that of the conventional teaching model in Civics Education to grade 6 students of the primary schools in Bali in the standard competence of practicing dharma agama and dharma negara.

Second, partially there is no significant difference in the students' Civics Education learning achievement in civic knowledge between the results of the implementation of teaching as yadnya model and that of the conventional teaching model in Civics Education to grade 6 students of the primary schools in Bali in the standard competence of practicing dharma agama and dharma negara.

Third, partially there is no significant difference in the students' Civics Education learning achievement in civic value orientation between the results of the implementation of teaching as yadnya model and that of the conventional teaching model in Civics Education to grade 6 students of the primary schools in Bali in the standard competence of practicing dharma agama and dharma negara.

Fourth,partially there also is no significant difference in the students' Civics Education learning achievement in civic behavior between the results of the implementation of teaching as yadnya model and that of the conventional teaching model in Civics Education to grade 6 students of the primary schools in Bali in the standard competence of practicing dharma agama and dharma negara.

Concerning the first aim of this study this experimental study produced the data as shown in Table 3. The results of the testing of the hypotheses using MANOVA are shown in Table 4.

Table3. Comparison of Averages for the Level of Civic Knowledge, Value Orientation, and Behavior between Experiment and Control Classes

\begin{tabular}{lllll}
\hline Ex-Con & & & Value Orient. & Behavior \\
\hline \multirow{3}{*}{$0=$ Control } & Mean & 59.68 & 79.73 & 73.07 \\
& N & 114 & 114 & 114 \\
& Std. Dev. & 13.45 & 9.78 & 11.36 \\
& & 67.63 & 83.40 & 67.17 \\
\multirow{3}{*}{ Experiment } & Mean & 157 & 157 & 157 \\
& N & 12.61 & 6.82 & 10.55 \\
& Std. Dev. & 64.29 & 81.85 & 69.65 \\
& & 271 & 271 & 271 \\
& Mean & 13.53 & 8.38 & 11.26 \\
\hline
\end{tabular}

Table 4. Result of Data Analysis by using MANOVA

\begin{tabular}{lllllll}
\hline Effect & & Value & F & Hypothesis df & Error df & Sig. \\
\hline \multirow{4}{*}{ Intercept } & Pillai's Trace & .991 & $10174.591(\mathrm{a})$ & 3.00 & 267.00 & .00 \\
& Wilks' Lambda & .009 & $10174.591(\mathrm{a})$ & 3.00 & 267.00 & .00 \\
& Hotelling's Trace & 114.321 & $10174.591(\mathrm{a})$ & 3.00 & 267.00 & .00 \\
& Roy's Largest Root & 114.321 & $10174.591(\mathrm{a})$ & 3.00 & 267.00 & .00 \\
experiment / & Pillai's Trace & .184 & $20.023(\mathrm{a})$ & 3.00 & 267.00 & .00 \\
control & Wilks' Lambda & .816 & $20.023(\mathrm{a})$ & 3.00 & 267.00 & .00 \\
& Hotelling's Trace & .225 & $20.023(\mathrm{a})$ & 3.00 & 267.00 & .00 \\
& Roy's Largest Root & .225 & $20.023(\mathrm{a})$ & 3.00 & 267.00 & .00 \\
\hline
\end{tabular}




\begin{tabular}{|c|c|c|c|c|c|c|}
\hline Source & $\begin{array}{l}\text { Dependent } \\
\text { Variable }\end{array}$ & $\begin{array}{l}\text { Type III Sum of } \\
\text { Squares }\end{array}$ & $\mathrm{df}$ & Mean Square & $\mathrm{F}$ & Sig. \\
\hline \multirow{3}{*}{ Corrected Model } & Z.KNOW. & 4173.336(a) & 1 & 4173.336 & 24.801 & .00 \\
\hline & Z.VALUE & 890.938(b) & 1 & 890.938 & 13.271 & .00 \\
\hline & Z.PERFORM & 2298.765(c) & 1 & 2298.765 & 19.355 & .00 \\
\hline \multirow{3}{*}{ Intercept } & Z.KNOW. & 1070436.798 & 1 & 1070436.798 & 6361.310 & .00 \\
\hline & Z.VALUE & 1757399.571 & 1 & 1757399.571 & 26177.250 & .00 \\
\hline & Z.PERFORM & 1298741.447 & 1 & 1298741.447 & 10935.176 & .00 \\
\hline \multirow{3}{*}{$\begin{array}{l}\text { experimenr / } \\
\text { control }\end{array}$} & Z.KNOW. & 4173.336 & 1 & 4173.336 & 24.801 & .00 \\
\hline & Z.VALUEI & 890.938 & 1 & 890.938 & 13.271 & .00 \\
\hline & Z.PERFORM & 2298.765 & 1 & 2298.765 & 19.355 & .00 \\
\hline \multirow{3}{*}{ Error } & Z.KNOW. & 45265.439 & 269 & 168.273 & & \\
\hline & Z.VALUE & 18059.211 & 269 & 67.135 & & \\
\hline & Z.PERFORM & 31948.406 & 269 & 118.767 & & \\
\hline \multirow{3}{*}{ Total } & Z.KNOW. & 1169387.755 & 271 & & & \\
\hline & Z.VALUE & 1834642.300 & 271 & & & \\
\hline & Z.PERFORM & 1348803.086 & 271 & & & \\
\hline \multirow{3}{*}{ Corrected Total } & Z. KNOW. & 49438.776 & 270 & & & \\
\hline & Z.VALUE & 18950.149 & 270 & & & \\
\hline & Z.PEFORM & 34247.171 & 270 & & & \\
\hline
\end{tabular}

Note:

a R Squared $=.084$ (Adjusted R Squared $=.081)$

b R Squared $=.047$ (Adjusted R Squared $=.043$ )

c R Squared $=.067$ (Adjusted R Squared $=.064$ ).

The results can be explained as follows. First, the implementation of Civics Education teaching as yadnya model has given a significant effect on Civics Education learning achievement of grade 6 students of primary schools in Bali in the aspect of civic knowledge, values and behavior compared to the implementation of the conventional Civics Education teaching model.

Second, the implementation of Civics Education teaching as yadnya model has given a significant effect on Civics Education learning achievement in the aspect of civic knowledge partially compared to the implementation of conventional Civics Education teaching model. The effect of teaching has contributed $8.4 \%$ to the variability of scores in the students' civic knowledge. The learning achievement in civic knowledge of the students is significantly better when they are taught through Civics Education teaching as yadnya model compared to that through the conventional Civics Education teaching model.

Third, the implementation of Civics Education Teaching as yadnya model has given a significant effect on Civics Education learning achievement in the aspect value orientation partially compared to the implementation of the conventional Civics Education teaching model. The effect of the teaching has contributed $4.7 \%$ to the variability of scores in the students in civic values. The learning achievement in civic value orientation is significantly better when they are taught through Civics Education teaching as yadnya model compared to that through the conventional Civics Education teaching model.

Fourth, the implementation of Civics Education Teaching as yadnya model has given a significant effect on Civics Education learning 
achievement in the aspect civic behavior partially compared to the implementation of the conventional Civics Education teaching model. The effect of the teaching has contributed $6.7 \%$ to the variability of scores in the students in civic behavior. The learning achievement in civic behavior is significantly better compared to that through the conventional Civics Education teaching model.

\section{Discussion}

An effective primary school Civics Education teaching based on yadnya was found in this research and the teaching syntax was developed into ten teaching phases. The ten phases were meant to improve the phases of teaching established in the process standard according to the Minister of National Education Regulation No. 41 of 2007 (http://www.scribd.com/doc/8754386/Permen-Standar-Proses-No-41. The steps of teaching Civics Education as yadnya that was followed using the syntax has turned out to be better than or producing significantly higher learning achievement especially in civic knowledge and value orientation compared to the result obtained from the implementation of the conventional teaching model.

This better students' learning achievement was actually expected, although in terms of the category of the quality of learning achievement it has not yet been optimal. The non optimal Civics Education learning achievement of the students is natural since the contribution of the teaching models (Civics Education teaching as yadnya versus the conventional Civics Education teaching model) to the variability of scores of the students' learning achievement in the aspect of civic knowledge was only $8.4 \%$ and in the aspect of civic value orientation it was only $4.5 \%$. The implementation of Civics Education teaching as yadnya can significantly improve the students' Civics Education learning achievement better than the implementation of the conventional teaching model. Some reasons that can account for this relation are as follows. First, the implementation of Civics Education teaching model as yadnya can give a better focus on the students' attention and learning moti- vation than the implementation of the conventional Civics Education teaching model.

Second, Civics Education teaching as yadnya is more solid in integrating all structures of the students' knowledge from sensory physiological, emotional, intellectual, social, moral, and spiritual domains. Hence, the students' knowledge becomes more complete, comprehensive, and meaningful. Learning Civics Education in a more meaningful manner, of course, also produces better learning achievement and civic values (DeVries dan Zan, 1994; Giroux and Pennao, 1979; NCSS, 2000; Sukadi, 2009).

Third, Civics Education teaching as yadnya gives the students the opportunity to learn in the core phases of teaching up to four levels of self-learning structure: brahmacari phase as the exploration phase, grehasta phase of group learning with the stressing on elaboration, learning with reflection and confirmation at wanaprasta phase, and practicing yadnya of knowledge at bhiksuka phase. On the other hand, in the conventional Civics Education teaching, the students just tend to learn in three levels: exploration, elaboration, and confirmation. Also in Civics Education teaching as yadnya the students do not only learn civic knowledge in the low cognitive level such as in the conventional teaching model, but they also learn to develop beliefs, values, and attitudes using a high level cognitive level in the aspects of problem solving (see Tim TOT NasionalEkspansi, 2010).

Fourth, the implementation of Civics Education teaching as yadnya enables the teacher to control and orient the emotional condition of the students in learning toward meaningful learning objectives, so that the teaching condition is more relaxed without any tension, more fun, and motivating the students to learn through the system of giving more reinforcements which are more positive, more varied and more appropriate. This atmosphere of teaching of course contributes to the students' Civics Education learning achievement in the aspects of civic knowledge and value orientation. The data on the students' learning achievement in the aspect of civic behavior or civic perfor- 
mance was significantly better in the results of the implementation of the conventional Civics Education teaching model. This learning achievement was not expected. The explanation of the rather contradictive result is as follows.

First, the civic performance test used in this study had a self evaluation format that focuses on the students' civic performance in doing their obligation or swadharma in the family, school and community environments. The aim of such teaching tends to be related to the conditioning pattern of the students' behavior in daily life. Three schools were involved as control groups in this study which had a strong commitment for so long time. The schools had disciplined their students' behaviors especially in the school environment and asked support from their parents to do the same in the family environment. The control over the students' disciplined behaviors does not only involve the use of the school disciplinary regulation that was firmed and real, but also involved the support from all teachers to monitor and strengthen the regulation.

At SD Laboratorium Undiksha and SD Dwijendra they even use the pocket book program to record good behaviors and offenses done by the students everyday in the school environment and family environment. The record of behaviors then even becomes data for assessing the students' behaviors for Civics Education in the school environment and family environment that will influence their school card scores for Civics Education. It seems that the conditioning of behavior like this is more measurable in self-evaluation format compared to measuring behaviors that develop from the classroom learning achievement factor. On the other hand, three out of five schools that were involved as the experiment class in this study did not pay much attention or used less control over the problem of conditioning or disciplining the students, both in the school environment and the family environment. The formation of the students' civic behavior in practicing their obligations or swadharma in the family, school and community environments tends to occur naturally as the effect of the classroom learning achievement.

Second, Civics Education teaching as yadnya that was implemented in the schools of the experiment class took place only in seven meetings and this was only in the Civics Education lesson. Perhaps, although the teaching factor could influence the students' behavior in practicing their obligations in the family, school, and community environments, the result was not more intensive and effective than the conditioning program or the discipline program that had been run by the schools for so long in the schools of the control group. Of course, if an effective Civics Education teaching as yadnya model is used followed by the students' behavior conditioning program in the school and family environments, the results will be much better.

\section{CONCLUSION}

The findings of this study are as follows. First, an effective primary school Civics Education teaching as yadnya model was developed from the syntax of teaching with 10 teaching phases. Second, descriptively Civics Education teaching as yadnya produced Civics Education learning achievement that fell into the fair category in the aspects of civic knowledge, the high category in the aspect of civic value orientation, and thefair category in the aspect of civic behavior. Third, the implementation of Civics Education teaching as yadnya model had a significant effect on the students' Civics Education learning achievement in the aspects of civic knowledge, value orientation, and behavior both simultaneously and partially.

In the light of the findings it is suggested to the primary school Civics Education teachers of grade 6 students in Bali, in particular, to implement Civics Education teaching as yadnya model that is supplemented by dharma agama and dharma negara. Material. The syntax of teaching used are 10 teaching phases.

The teachers need to develop variations in the syntax of teaching that are more effective to synergize all systems of knowledge of the students (sensory physiological, emotional, so- 
cial, intelectual, academic, moral, anda spiritual); developing various relevant teaching material supplements; studying the effect of teaching on the control of tri guna dispositions (satwam, rajas, dan tamas); developing more complete students' learning achievement taxonomy in line with the taxonomy of the teaching of parisudha (thinking appropriately and correctly/ manacika, talking appropriately and correctly/ wacika, and doing wisely and correctly kayika); developing a model of process assessment and product assessment for Civics Education learning achievement based on authentic assessment and developing learning achievement measurement for the aspects of values, moral, feeling and emotion, awareness, and civic social skill and spiritual awareness of the students.

\section{AKNOWLEDGEMENT}

This study were supported by many parties. Therefore, on this occasion, the author expresses his gratitude and appreciation to:

- Directorate General of Higher Education, The Ministry of Education and Culture and colleagues at the Department of Civics Education, Faculty of Social Sciences (FIS) Ganesha University of Education (Undiksha) Singaraja, Bali Province.

- Teachers at primary schools in Bali Province that were involved in this study, and other people who have supported this activity both directly and indirectly.

- Editor of Jurnal Cakrawala Pendidikan who has been willing to publish this article as the effort of publishing results of studies under the scheme Penelitian Hibah Bersaing at the second stage of 2010 .

May all the supports form yadnya or a sincere holy dedication or worship to God.

\section{REFERENCES}

Budimansyah dan Sapriya. 2012. "Refleksi Implementasi Project Citizen dalam Pembelajaran Pendidikan Kewarganegaraan di Indonesia". Dimensi-dimensi Praktik Pendidikan Karakter. Bandung: Widya Aksara Press.
Borg, W. R. and M. D. Gall. 1989. Educational Research: An Introduction. Fifth Edition. New York and London: Longman.

Depdiknas. 2004. Pedoman Penyelenggaraan Program Kecakapan Hidup (Life Skills) Pendidikan Non Formal. Jakarta: Depdiknas.

DeVries, R. and Zan, B. 1994. Moral Classrooms, Moral Children: Creating a Constructivist Atmosphere in Early Education. New York and London: Teachers College Press.

Djahiri, H. A. K. 2006. "Esensi Pendidikan Nilai-Moral dan PKN di Era Globalisasi”. dalam D. Budimansyah dan S. Syam (ed). Pendidikan Nilai Moral dalam Dimensi Pendidikan Kewarganegaraan. Bandung: Lab. PKN FPIPS-UPI. Hal. 313.

Fukuyama, F. 1985. "Confusianism and Democracy”. Journal of Democracy, 6 (3) April, 20-33.

Giroux, H. and Pennao A. 1979. "Social Education in the Classroom: The Dynamics of the Hidden Curriculum". Theory and Research in Social Education, 7,21-42.

Merdhana I N. 2000. "Kurikulum Muatan Lokal pada Sekolah Menengah Kejuruan di Bali”. Majalah Ilmiah Aneka Widya. WII (3), 12-21.

NCSS. 2000. National Standards for Social Studies Teachers. Volume 1. Washington, DC: National Council for the Social Studies.

Norusis, M.J. 1986. Advanced Statistics: SPSS/ $P C+$ for the IBM PC/XT/AT. Chicago, Il: SPSS Inc. 
Pai, Y. 1990. Cultural Foundations of Education. New York: Macmillan Publishing Company.

Permendiknas RI Nomor 41 Tahun 2007. Standar Proses untuk Satuan Pendidikan Dasar dan Menengah. http://www.scribd.com/doc/8754386/Permen-Standar-Proses-No-41. Diunduh tanggal 20 November 2010 .

Soeprapto, 2013. "Landasan Aksiologis Sistem Pendidikan Nasional Indonesia dalam Perspektif Filsafat Pendidikan", dalam Jurnal Cakrawala,XXXII (2), hlm. 266276.

Somantri, M. N. 2001. Menggagas Pembaharuan Pendidikan IPS. Bandung: PT Remaja Posdakarya.

Subagia, I.W. 2006. "Pengembangan Model Siklus Belajar Berdasarkan Potensi-Potensi Kearifan Lokal Masyarakat Bali dalam Bidang Pendidikan (Studi Pengembangan Model Siklus Belajar Berbasis Budaya. Laporan Penelitian Hibah Bersaing Lanjutan. Tidak Dipublikasikan. Singaraja: Universitas Pendidikan Ganesha.

Subagia, IW. 2000. "Balinese Indigenous Worldview and Its Role in The Reforms of Science Education in Bali”, Majalah Ilmiah Aneka Widya”, XXXIII (3), hlm. 71-81.
Subiyantoro. 2013. "Pengembangan Model Pendidikan Nilai Humanistik-Religius Berbasis Kultur Madrasah". Jurnal Cakrawala Pendidikan, XXXII (3), hlm. 326340 .

Sukadi. 2009. Belajar dan Pembelajaran (Bermuatan Konsep-konsep Kearifan Lokal. Singaraja: Undiksha.

Sukadi. 2006. "Pendidikan IPS sebagai Rekonstruksi Pengalaman Budaya Berbasis Ideologi Tri Hita Karana (Studi Etnografi tentang Pengaruh Masyarakat terhadap Pelaksanaan Program Pendidikan IPS di SMA Negeri 1 Ubud)". Disertasi. Tidak Dipublikasikan. Bandung: UPI Bandung.

Tim TOT Nasional-Ekspansi. 2010. Pembelajaran Aktif di Sekolah dan Kunjungan Sekolah: Panduan untuk Fasilitator. Jakarta: DBE-2 dan USAID.

Widja, I G. 2007. "Membangun Kembali Jiwa Pendidikan dalam Sistem Persekolahan Kita (Satu Tinjauan Cultural Studies)", Jurnal Pendidikan dan Pengajaran, Universitas Pendidikan Ganesha, Vol. 40 (1), hlm. 74 -87.

Winataputra, U.S. 2001. "Jati diri Pendidikan Kewarganegaraan sebagai Wahana Sistemik Pendidikan Demokrasi (Suatu Kajian Konseptual dalam Konteks Pendidikan IPS)". Disertasi. Tidak dipublikasikan. Bandung: Universitas Pendidikan Indonesia. 